\title{
Light-induced absorbance changes associated with photoinhibition and pigments in nitrifying bacteria
}

\author{
Maria A. Guerrero, Ronald D. Jones* \\ Southeast Environmental Research Program and Department of Biological Sciences, Florida International University, \\ University Park, Miami, Florida 33199, USA
}

\begin{abstract}
Spectroscopic analysis of nitrifying bacteria revealed the presence of a porphyrin-like pigment with an absorption maximum at $408 \mathrm{~nm}$. The photoresponsive pigment accumulated during the late exponential phase of growth. The photoreceptor was found at higher concentrations in $\mathrm{NH}_{4}{ }^{+}$ oxidizers than in $\mathrm{NO}_{2}^{-}$oxidizers. When absorbance scans and action spectra of the nitrifiers were compared, it was found that the regression between the degree of photoinhibition and higher absorbances at $408 \mathrm{~nm}$ was significant $\left(\mathrm{r}^{2}=0.7\right)$. Reversible light-induced absorbance changes were observed in vivo and in vitro. Absorbance changes were maximally elicited by light in the $400 \mathrm{~nm}$ region for both types of nitrifiers, but the change was only significant $(p<0.05)$ for $\mathrm{NH}_{4}^{+}$oxidizers. This spectral sensitivity of the $\mathrm{NH}_{4}{ }^{+}$oxidizing process suggests that the absorbance change observed is related to the blue light sensitivity of $\mathrm{NH}_{4}{ }^{+}$oxidizers.
\end{abstract}

KEY WORDS: Photoinhibition · Nitrifying bacteria $\cdot$ Nitrification

\section{INTRODUCTION}

The damaging effects of light on microbes may impose constraints on some of their activities. For instance, the process of nitrification $\left(\mathrm{NH}_{4}{ }^{+}\right.$and $\mathrm{NO}_{2}{ }^{-}$oxidation) in nitrogen turnover has been repeatedly shown as light sensitive (Schön \& Engel 1962, Smith 1977, Olson 1981, Yoshioka \& Saijo 1984, Diab \& Shilo 1988, Vanzella et al. 1989). Marine habitats offer a good system to study the effect of the repetitive diurnal variation in light intensity. Similarly, marine nitrifying bacteria offer a tentative test organism to look at how exposure to light can affect their activities. The differential light sensitivity of marine nitrifiers has led investigators to make important implications for nitrification in marine environments (e.g. formation of primary nitrite maxima; Olson 1981). However, the physiology behind the photoinactivation of ammonium and nitrite oxidizing bacteria needs characterization, as a prerequisite to making any prediction on the process in which they are involved. This paper approaches this problem by spectroscopic analysis of the usual pig-

•E-mail: serp@fiu.edu ments (i.e. cytochromes) and of the light absorption characteristics of whole cell suspensions of nitrifiers. These observations were carried out to elucidate possible chromophore(s) present and to examine their relationship to the observed light response. Such measurements might provide an experimental basis to explore the photobiological control mechanisms of photoinhibition.

\section{MATERIALS AND METHODS}

Microorganisms and growth conditions. The marine ammonium oxidizing bacteria Nitrosomonas cryotolerans (ATCC 49181; Jones et al. 1988) and Nitrosococcus oceanus (ATCC 19707) along with the marine nitrite oxidizing bacteria Nitrococcus mobilis (ATCC 25380) and Nitrobacter sp. (Nb 297, provided by S. W. Watson) were grown in continuous cultures and harvested as described previously (Guerrero \& Jones 1996a). For the experiments that required batch cultures, the same culture media was used with the addition of $\mathrm{N}$-2-hydroxyethylpiperazine-N'-2-ethanesulfonic acid (HEPES) as a buffer. The flask cultures 
were kept in a rotatory shaker and incubated at $25^{\circ} \mathrm{C}$.

Preparation of crude extracts. Cells were harvested by centrifugation from chemostat cultures, washed twice in $0.2 \mu \mathrm{m}$ filtered sea water (FSW), and resus-

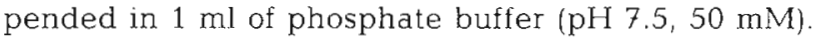
The cell suspension was placed in a $1.5 \mathrm{ml}$ polyethylene microfuge tube and sonicated on ice for 3 min (Tekmar Sonic Disruptor, $15 \mathrm{~W}$ ). The cellular debris was separated by microcentrifugation at $15000 \times g$ for $5 \mathrm{~min}$.

Absorbance studies. Absorbance scans: Absorption spectra of whole cell suspensions or cell-free extracts were measured at room temperature with a singlebeam spectrophotometer (HP 8452A diode array) on line with a PC equipped with MS-DOS UV/VIS software, Version $\mathbf{1} .0$. Baseine measurements (phosphate buffer or FSW) were substracted automatically from sample scans. Absolute spectra are presented in either the reduced or oxidized state. Reduced scans were obtained by adding a few crystals of $\mathrm{Na}_{2} \mathrm{~S}_{2} \mathrm{O}_{4}$ to the cuvette that held the standard cell suspension. Oxidized scans were attained by vigorous aeration of the respective cuvette. Wavelength range for the scans was recorded and stored at $2 \mathrm{~nm}$ intervals.

Absorptivity changes: Absorbance changes in vivo and in vitro, were detected by absorption spectra of samples and controls before and after irradiation. For these experiments whole cells or extracts were resuspended in $0.05 \mathrm{M}$ phosphate buffer ( $\mathrm{pH} 7.5$ ), instead of FSW. Monochromatic irradiation of the samples was carried out as described by Guerrero \& Jones (1996a). Action spectra for the absorbance change induced by different wavelengths of light of equal fluence $\left(25 \mathrm{~W} \mathrm{~m}^{-2}\right)$ were determined by measuring absorbance scans in triplicates just before irradiation $\left(T_{0}\right)$ and 30 min after $\left(T_{30}\right)$. A portion of the cell suspension was saved for protein determinations (Lowry et al. 1951), and results were normalized to $\triangle$ Absorbance per mg of cell protein.

Cytochrome spectra. Whole cells: Reduced minus oxidized difference spectra were determined as follows: $250 \mathrm{ml}$ of chemostat culture was harvested by centrifugation, washed twice in FSW and resuspended in phosphate buffer ( $\mathrm{pH} 7.8$ ) to an $\mathrm{OD}_{660}$ (optical density at $660 \mathrm{~nm}$ ) of at least 1.2 Absorbance. This optically thick cell suspension was used to run a differential scan with a split beam spectrophotometer (Perkin Elmer Lambda $4 \mathrm{~B}$ ). $\mathrm{Na}_{2} \mathrm{~S}_{2} \mathrm{O}_{3}$ crystals were used to reduce one cuvette, while vigorous aeration before scanning was used to keep the other cuvette oxidized. The oxidizing effect of aeration was similar to adding $10 \mu \mathrm{l}$ of a $30 \% \mathrm{H}_{2} \mathrm{O}_{2}$ solution. Published extinction coefficients were used to estimate the amount of cytochrome per mg of cell protein (Smith 1977).

Cell-free extracts: For cytochrome determinations on crude preparations of cell membranes and cell-free supernatant fractions, the cells were ruptured by sonication. After sonication, the cells that were not lysed were separated by microcentrifugation $(15000 \times g$ for 15 min; Miller \& Wood 1982). The sediment was taken as a crude preparation of cell membrane and the cellfree supernatant as the soluble (periplasmic + cytoplasmic) fraction. The rest of the procedure was as described above for whole cell suspensions.

Analytical methods. Total protein was determined within $48 \mathrm{~h}$ by Lowry's (1951) method using bovine serum albumin as standard. Samples were collected in triplicates, and the data points correspond to the mean of the triplicates. Correlation analyses ( $r$ ) and Student t-tests were used to determine relationships between variables and statistical significance, respectively.

\section{RESULTS}

\section{Absorption spectra of cells}

In vivo absorption characteristics can give an indication of the possible chromophore(s) present in the cells. Like other cells, nitrifying bacteria exhibited at least a biphasic absorption, with a first maxima at $280 \mathrm{~nm}$ that fits the absorption spectrum of proteins and nucleic

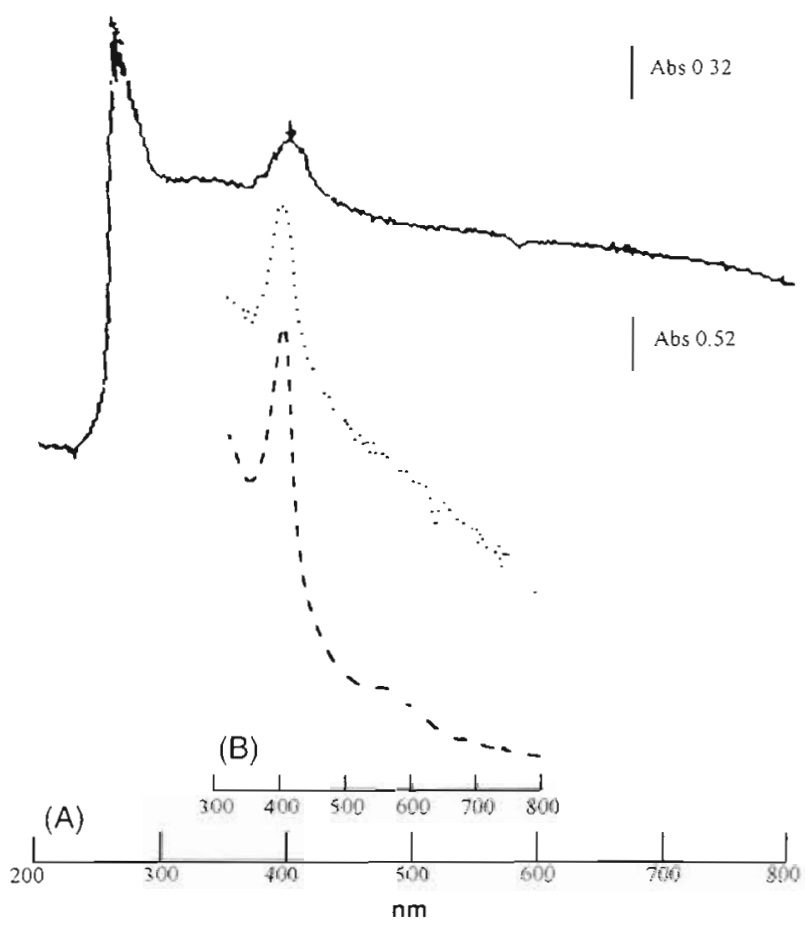

Fig. 1. Absorbance scans of Nitrosomonas cryotolerans as a prototype of nitrifiers' absorbance. (A) Wavelength range: 200 to $800 \mathrm{~nm}_{i}(-)$ whole cells. (B) Wavelength range: 300 to $800 \mathrm{~nm} ;(\ldots)$ whole cells, ( - - ) crude-extract. Protein concentration: $0.5 \mathrm{mg} \mathrm{m}^{-1}$. Abs: absorbance 
acids and a second at 408 to $410 \mathrm{~nm}$ (Fig. 1). A great deal of scattering was found when working with whole cell suspensions, which did not allow for 'smooth' resoIution of the scans. It was possible to avoid scattering noise by using cell-free extracts instead of whole cells. This approach did not alter the maxima readings (Fig. 1), since the maximum absorption peak still showed up at $408 \mathrm{~nm}$ using either a whole cell suspension or cell-free extracts.

Absorption scans with cell-free extracts were performed to determine the potential chromophore in all the species studied (Fig. 2A). For comparison purposes, all of the cell suspensions were adjusted to a standard protein concentration within the range of 420 to $580 \mu \mathrm{g}$ protein $\mathrm{ml}^{-1}$. Absorbance characteristics of the 4 different species tested were qualitatively similar, since they all showed an absorption maximum at $408 \mathrm{~nm}$ in the oxidized state. The difference between species was observed to be mainly quantitative with respect to the $408 \mathrm{~nm}$ peak (Table 1 ).

It was also of interest to see how the absorbance characteristics of the cells correspond with their respective action spectra. When absorbance scans and previously published action spectra (Guerrero \& Jones 1996a) were superimposed, it was consistently observed that the degree of photoinhibition directly correlated with higher absorbances at $408 \mathrm{~nm}$ (Fig. 3). For example, $\mathrm{Ni}$ trobacter $\mathrm{sp}$. appeared as the organism with least absorbance $\left(\mathrm{Abs}_{408} \mathrm{mg}^{-1}\right.$ cell protein: 0.088) and also least photosensitivity (ca $5 \%$ ) as opposed to Nitrosomas cryotolerans which showed the highest absorbance $\left(\right.$ Abs $_{408} \mathrm{mg}^{-1}$ cell protein: 0.326 ) as well as the highest photosensitivity (up to $82 \%$; Table 1). Nitrosococcus oceanus was the only organism that did not fit this pattern. Interestingly, $N$. oceanus is also the only member of the $\mathrm{NH}_{4}{ }^{+}$oxidizers that has been classified in a phylogenetically different group (Woese et al. 1985).

The chromophore seemed to accumulate during the late exponential phase of growth of the culture. Cells from an early exponentially growing culture (3 d old batch-culture; Table 2) had approximately 10 to $70 \%$

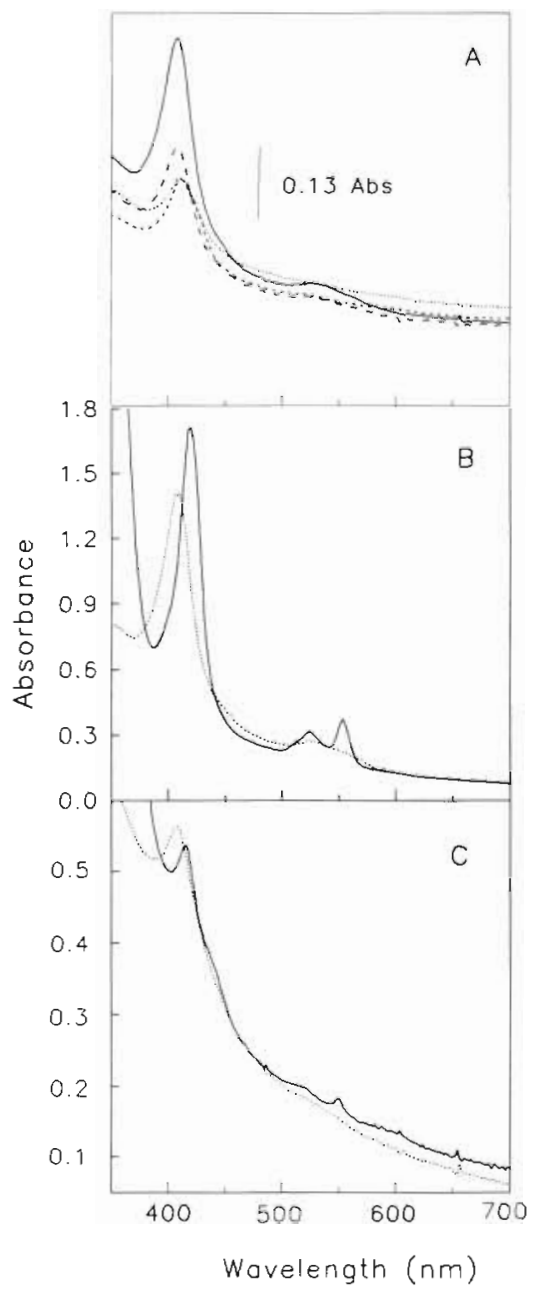

Fig. 2. (A) Absorption scans of cell-free extracts of nitrifying bacteria. (-) Nitrosomonas cryotolerans; (- - ) Nitrosococcus oceanus; $(. . . .$.$) Nitrococcus mobilis; (\ldots . . .$.$) Nitrobacter sp.$ Protein concentrations were $0.5,0.58,0.46$, and $0.48 \mathrm{mg} \mathrm{m}^{-1}$, respectively. (B) Oxidized versus reduced absorbance scans of cell-free extracts of $N$. cryotolerans. (........) Oxidized absorbance scan; (-) dithionite-reduced absorbance scan. Protein concentration: $0.5 \mathrm{mg} \mathrm{ml}^{-1}$. (C) Oxidized versus reduced absorbance scans of cell-free extracts of Nitrobacter

sp. Protein concentration: $0.46 \mathrm{mg} \mathrm{m}^{-1}$ Abs: absorbance

Table 1. Pigment concentration per mg of cell protein. Abs 408 : absorbance at $408 \mathrm{~nm}$

\begin{tabular}{|c|c|c|c|c|}
\hline Microorganism & $\mathrm{Abs}_{408}$ & $\begin{array}{l}\text { Protein concentration } \\
\qquad\left(\mathrm{mg} \mathrm{ml}^{-1}\right)\end{array}$ & $\begin{array}{l}\text { Absorbance } \mathrm{mg}^{-1} \\
\text { cell protein }\end{array}$ & $\begin{array}{l}\text { Percent } \\
\text { inhibition }{ }^{a}\end{array}$ \\
\hline Nitrosomonas cryotolerans & 0.163 & 0.5 & 0.326 & $82^{\mathrm{b}}$ \\
\hline Nitrosococcus oceanus & 0.073 & 0.58 & 0.126 & $75^{\mathrm{b}}$ \\
\hline Nitrococcus mobilis & 0.057 & 0.46 & 0.124 & $25^{c}$ \\
\hline Nitrobacter sp. $(25 \mathrm{~W} 30 \mathrm{~N})$ & 0.042 & 0.48 & 0.088 & $5^{c}$ \\
\hline \multicolumn{5}{|c|}{$\begin{array}{l}\text { a Light inhibition experiments were conducted in the same way as in Guerrero \& Jones (1996a) } \\
\text { b\% inhibition of } \mathrm{NH}_{4}{ }^{+} \text {oxidizing activity at } 400 \mathrm{~nm}(25 \mathrm{~W} \mathrm{~m} \text {-2) after a } 2 \mathrm{~h} \text { irradiation } \\
\mathrm{c} \% \text { inhibition of } \mathrm{NO}_{2} \text { oxidizing activity at } 400 \mathrm{~nm}\left(25 \mathrm{~W} \mathrm{~m}^{-2}\right) \text { after a } 4 \text { h irradiation }\end{array}$} \\
\hline
\end{tabular}




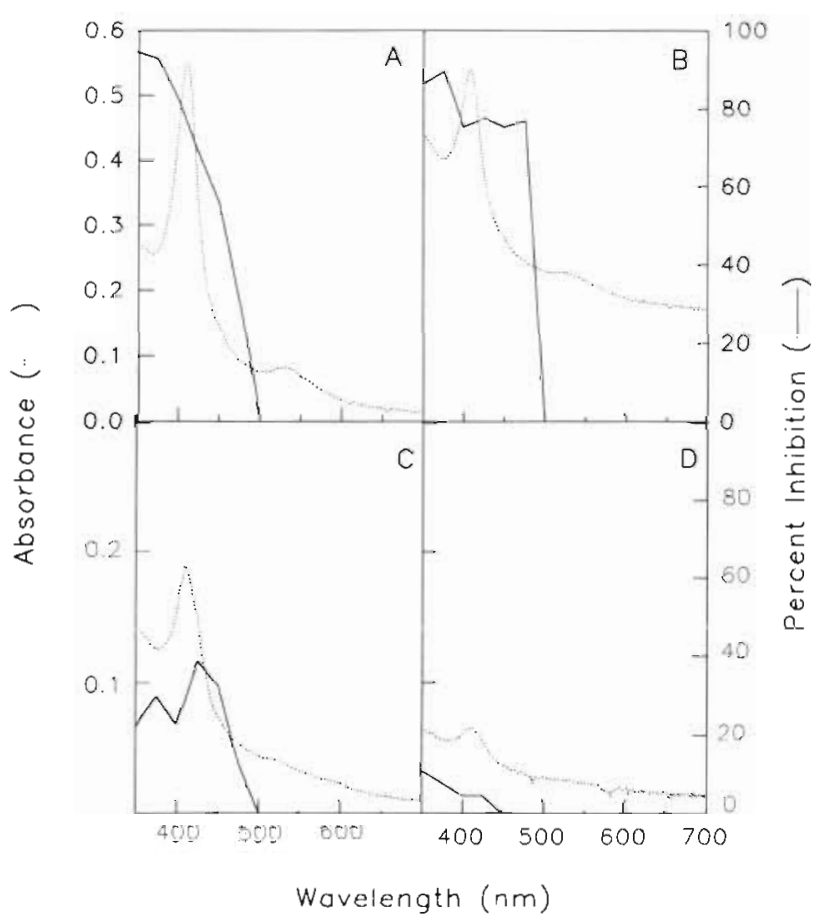

Fig. 3. Action spectrum versus absorbance scan. (A) Nitrosomonas cryotolerans, (B) Nitrosococcus oceanus, (C) Nitrococcus mobilis, (D) Nitrobacter sp. Protein concentrations as in Fig. 2A. (-) Percent inhibition; ( ......) absorbance scan of cellfree extract. Action spectra are from Guerrero \& Jones (1996a)

of the pigment found in cells from the late exponential

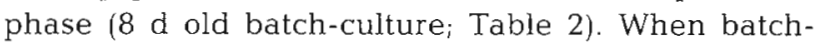
cultured cells were used for photoinhibition experiments, the greatest loss in activity was obtained with the older cultures as compared to the younger cultures $\left(r^{2}=0.84\right)$.

\section{Absorbance change}

Light-induced absorbance changes were detected in the pigment found at $408 \mathrm{~nm}$
By measuring the extent of the absorbance change provoked by different wavelengths ( 375 to $500 \mathrm{~nm}$ ) of equal light intensities, it was possible to construct the action spectrum for the light-induced absorbance change. In Fig. 4, absorbance changes are normalized to $\triangle \mathrm{Abs} \mathrm{mg}^{-1}$ cell protein. The action spectrum of Nitrosomonas cryotolerans shows a maximum at about $400 \mathrm{~nm}$ which closely corresponds to the absorption maximum $(408 \mathrm{~nm})$ of the pigment found in both whole cells and crude extracts (Fig. 4A). Nitrobacter sp. also showed significant changes in absorbance $(\mathrm{p}<0.05)$ effected by the same wavelengths (Fig. $4 \mathrm{~B}$ ). Its action maximum was also found at $400 \mathrm{~nm}$, yet the extent of the absorbance change was not as distinct as for $N$. cryotolerans or Nitrosococcus oceanus.

\section{Cytochrome composition}

Reduced minus oxidized difference spectra revealed a relatively uniform cytochrome composition for ammonium oxidizers and for nitrite oxidizers. It should be noted that electron transport chains are fairly versatile and vary according to changing conditions such as $\mathrm{pH}$, temperature, $\mathrm{pO}_{2}$, substrate, etc.; therefore, these results apply only to the growth conditions used in these experiments.

Dithionite-reduced minus oxidized difference spectra of Nitrosomonas cryotolerans and Nitrosococcus oceanus revealed 4 maxima at $421,520,550-552$ along with a subtle peak at $603 \mathrm{~nm}$ (Fig. 5A, B). The relatively broad peak in the 550-552 $\mathrm{nm}$ region along with the absorption maxima at 421 and $520 \mathrm{~nm}$ are indicative of c-type cytochrome(s). The $603 \mathrm{~nm}$ absorption band corresponds to cytochrome a (cyt-a). The concentration of cyt-c as estimated by using published extinction coefficients (Table 3; Smith 1977) was in the range of 8.7 to 13 and 5.7 to $7.5 \mu \mathrm{mol} \mathrm{\textrm {mg } ^ { - 1 }}$ cell protein, respectively. Cyt-a was found in lower amounts, in the order of 1.7 to $1.9 \mu \mathrm{mol} \mathrm{mg} \mathrm{mg}^{-1}$ cell protein.

Table 2. Culture dependent accumulation of $408 \mathrm{~nm}$ pigment. Abs $_{408}$ : absorbance at $408 \mathrm{~nm}$

\begin{tabular}{|c|c|c|c|c|}
\hline Organism & $\mathrm{Abs}_{408}$ & $\begin{array}{l}\text { Protein concentration } \\
\qquad\left(\mathrm{mg} \mathrm{ml}^{-1}\right)\end{array}$ & $\begin{array}{l}\text { Absorbance } \mathrm{mg}^{-1} \\
\text { cell protein }\end{array}$ & $\begin{array}{l}\text { Percent } \\
\text { inhibition }\end{array}$ \\
\hline \multicolumn{5}{|c|}{ Nitrosomonas cryotolerans } \\
\hline $3 \mathrm{~d}$ (batch) & 0.0057 & 0.045 & 0.126 & 50 \\
\hline $8 \mathrm{~d}$ (batch) & 0.0170 & 0.105 & 0.161 & 68 \\
\hline Chemostat & 0.1292 & 0.348 & 0.67 & 30 \\
\hline \multicolumn{5}{|c|}{ Nitrosococcus oceanus } \\
\hline $3 \mathrm{~d}$ (batch) & 0.0004 & 0.037 & 0.0108 & 59 \\
\hline $8 \mathrm{~d}$ (batch) & 0.0118 & 0.092 & 0.128 & 69 \\
\hline Chemostat & 0.155 & 0.788 & 0.196 & 70 \\
\hline \multicolumn{5}{|c|}{$0 \%$ inhibition after $475 \mathrm{~nm}$ irradiation $\left(2 \mathrm{~h}, 25 \mathrm{~W} \mathrm{~m}^{-2}\right)$} \\
\hline
\end{tabular}




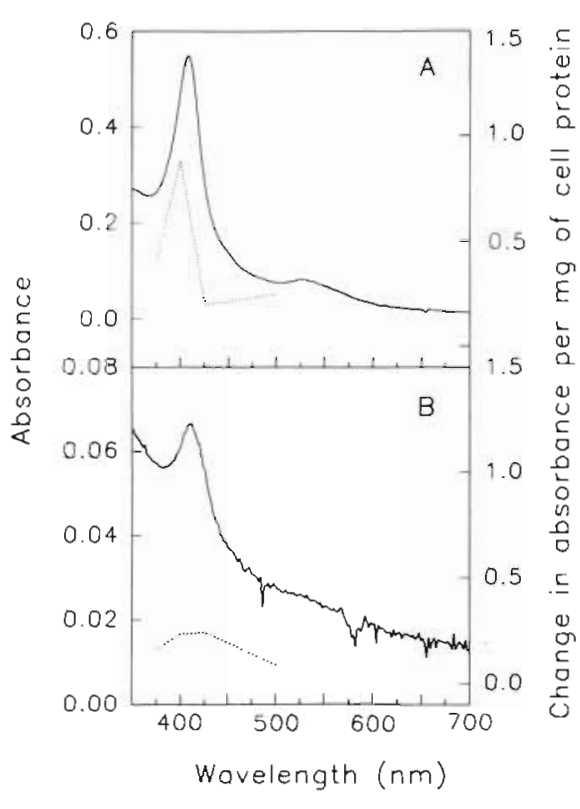

Fig. 4. Action spectrum of the light-induced absorbance change of the $408 \mathrm{~nm}$ chromophore versus absorption scans. (A) Nitrosomonas cryotolerans; $0.5 \mathrm{mg}$ protein $\mathrm{ml}^{-1}$ (B) Nitrobacter sp.; $0.48 \mathrm{mg}$ protein $\mathrm{ml}^{-1}$. (-) Absorption spectrum; ( ) change in absorbance per $\mathrm{mg}$ of cell protein

Nitrococcus mobilis and Nitrobacter sp. (25W30N) also shared a similar cytochrome constitution (Fig. 5C, D). Dithionite-reduced minus oxidized difference spectra showed absorption maxima at 418 and $440 \mathrm{~nm}$ in the soret region and at 520,550 and $590 \mathrm{~nm}$ in the visible region of the spectrum. The absorption bands at 418,520 and $550 \mathrm{~nm}$ correspond to cyt- $c$ and the ones at 440 and $590 \mathrm{~nm}$ belong to cyt-a (DiSpirito et al. 1985).

Nitrite oxidizers exhibited quantitative differences among their cytochrome components. Nitrobacter sp. showed more of a cyt-a component $(2.6$ to $4.76 \mu \mathrm{mol}$ $\mathrm{mg}^{-1}$ cell protein) than Nitrococcus mobilis $(0.68$ to

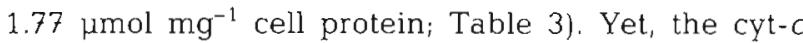
portion in $N$. mobilis was lower (1.8 to $2.4 \mu \mathrm{mol} \mathrm{mg}^{-1}$ cell protein) than in Nitrobacter sp. (4 to $6.2 \mu \mathrm{mol} \mathrm{mg}^{-2}$ cell protein). When ammonium oxidizers were fractionated, the precipitate (crude membrane) as well as

Table 3. Cytochrome composition and concentration (umol $\mathrm{mg}^{-1}$ cell protein). Cyt-a reduced-oxidized $\Delta \epsilon \mathrm{mM}: 20.5 /$ heme; Cyt-c reduced-oxidized $\Delta \in \mathrm{mM}: 17.3$

\begin{tabular}{|lcr|}
\hline Microorganism & Cyt-a & Cyt-C \\
\hline Nitrosomas cryotolerans & 1.9 & $8.7-13$ \\
Nitrosococcus oceanus & $<1.9$ & $5.7-7.5$ \\
Nitrococcus mobilis & $0.68-1.77$ & $1.8-2.4$ \\
Nitrobacter sp. & $2.6-4.76$ & $4-6.2$ \\
\hline
\end{tabular}
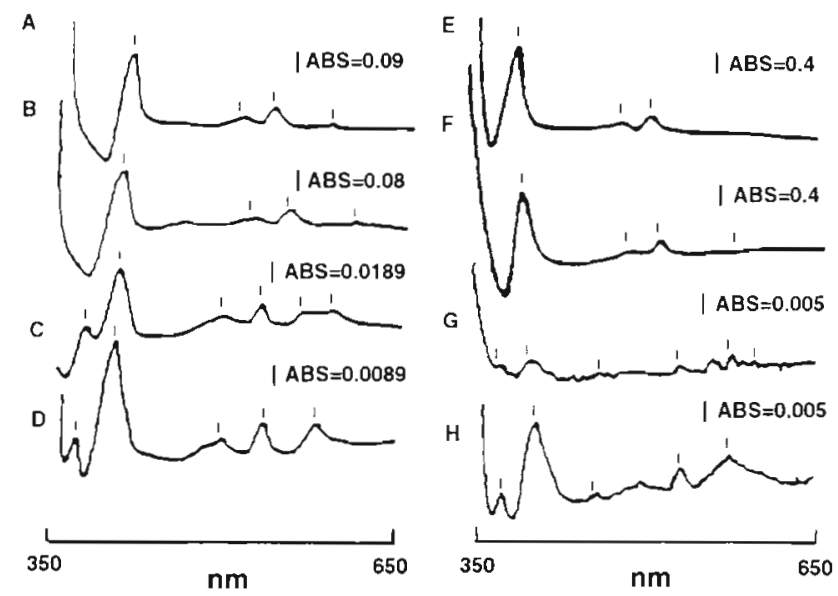

Fig. 5. Dithionite-reduced minus oxidized difference spectra of (A to D) whole cells and ( $E$ to $\mathrm{H})$ soluble and particulate fractions. (A) Nitrosomonas cryotolerans $\left(0.44 \mathrm{mg} \mathrm{m}^{-1}\right)$, (B) Nitrosococcus oceanus $\left(0.75 \mathrm{mg} \mathrm{ml}^{-1}\right)$; peaks were at 408 , 520,550 and $603 \mathrm{~nm}$. (C) Nitrococcus mobilis $\left(0.31 \mathrm{mg} \mathrm{m}^{-1}\right)$,

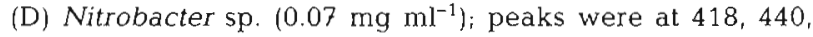
520,550 and $590 \mathrm{~nm}$. (E, F) N. cryotolerans soluble (E) and crude-membrane (F) fractions; protein concentration: $0.3 \mathrm{mg}$ $\mathrm{ml}^{-1}$ (G, H) Nitrobacter $\mathrm{sp}$. (25W30N) soluble (G) and crudemembrane $(H)$ fractions; protein concentration: $0.026 \mathrm{mg}$ $\mathrm{ml}^{-1}$. ABS: absorbance

the soluble (periplasmic + cytoplasmic) portion showed an analogous cytochrome make-up (Fig. 5E, F). In contrast, nitrite oxidizers appeared as having cytochromes preferentially located in the membrane fraction (Fig. 5G, H).

The dithionite-reduced cell-free extracts of ammonium and nitrite oxidizers confirm the presence of a mostly c-type cytochrome in the supernatant of the crude extracts, because of its characteristic absorption maxima at 418,520 and $550 \mathrm{~nm}$. Without attempting to isolate cytochromes, but by preparing cell-free extracts of the nitrifying bacteria, it was possible to obtain cyt-c-like oxidized absorption spectra (Fig. 2B, C) similar to those found by DiSpirito et al. (1985). Thus, this technique provided an easy and dependable way to more precisely look into photoprocesses regarding $c y t-c$ in these bacteria.

\section{DISCUSSION}

Absorption scans of fresh whole cells or cell-free extracts of nitrifying bacteria showed the presence of a broad peak at $408 \mathrm{~nm}$ which had a much higher absorbance than any other wavelength in the 300 to $500 \mathrm{~nm}$ range. The $408 \mathrm{~nm}$ absorption maximum was found in different proportions in all 4 species tested. Typically, there was a corresponding greater blue light sensitivity due to increasing pigment concentra- 
tions (Table 1). One of the potential chromophores for this region of the spectrum are porphyrins. Porphyrins are universal in aerobic organisms inasmurh as cells have hemes, cytochrome and cytochrome oxidase. Porphyrins are also characterized by strong absorption maxima in the soret region (400 to $420 \mathrm{~nm}$; Giese 1971, Jagger 1983); therefore, it was speculated that a porphyrin-containing pigment, such as a cytochrome, may act as the photoreceptor. Earlier work by Bock (1965) postulated that cytochrome-c specifically was affected by light, as it was 'photooxidized' in both Nitrosomonas sp. and Nitrobacter sp. after illumination. The light fluences used, however, were very high (>50 $\mathrm{W} \mathrm{m}^{-2}$ ) and this makes 'photobleaching' a more likely explanation (Müller-Neuglück \& Engel 1961, Epel \& Butler 1969). High light doses have been shown to provoke pigment photobleaching in other systems; Zea mays, Neurospora crassa (Brain et al. 1977), and Prototheca zopfii (Epel $\&$ Butler 1969). It is safe to assume that the fluences used in this work did not lead to photobleaching since dark recovery of nitrifying activity occurred previously (Guerrero \& Jones 1996a, b) when using identical light doses

Prior to this study soluble and membrane-bound cytochrome- $c$ had been characterized among nitrifiers (Miller \& Wood 1982, Tanaka et al. 1983, DiSpirito et al. 1985, Kirstein et al. 1986, Tsai \& Tuovinen 1989, Hooper et al. 1991). The cell-free extract system used in this work showed properties very similar to the above cited purified oxidized or reduced cyt-c fraction (DiSpirito et al. 1985; Fig. 2B, C). When these cyt-c like fractions (cell-free extracts) were used to detect light-induced absorbance changes, the most distinct changes in absorbance were observed at approximately $400 \mathrm{~nm}$ for both Nitrosomonas sp. and Nitrobacter sp., the difference being that the extent of the absorbance change was always greater for ammonium oxidizers (Fig. 4A, B). Notably, changes in absorbance were more distinct in cell-free extracts than in whole cells, which may be a reflection of the loss of reducing agents normally found within intact cells as opposed to when the cells are broken. These results demonstrate that at low light intcnsitios (i.c. $<25 \mathrm{~W} \mathrm{~m}^{-2}$ ), a ubiquitous cyt-c-like compound in the periplasm of nitrifying bacteria can become photooxidized and that this effect is reversible. c-Cytochromes of ammonium oxidizing bacteria are characteristically part of multiheme proteins, such as hydroxylamine oxidoreductase (HAO) and cyt- $c_{554}$ (Hooper et al. 1991). Since c-cytochromes have both a catalytic ( $\mathrm{HAO}$ ) and electron-transfer role (cyt- $\left.C_{554}\right)$, growth of ammonium oxidizers in light may be affected by inhibition of cytochrome function and not by cytochrome destruction.
Consequently, photoinactivation with blue light would depend on both: light dose and/or abundance of soluble cyt-c in the cells (Table 3 ).

Abundance of the chromophore (c-heme) corresponded to growth phase. Its accumulation is greater during the late exponential phase. Ecologically this might be significant, since cells from an early exponential phase of growth would be more light-tolerant than cells from subsequent stages. Therefore, conditions that favor exponential growth (waste-water treatment plants) are not expected to show major photoinhibition of nitrification. The opposite would be expected in oligotrophic waters such as the open ocean.

Under autotrophic growth conditions, ammonium oxiduzers had a fairiy uniform cytochrome cumposition with a broad peak for the cyt-c (550 to $554 \mathrm{~nm}$ ) component and a barely detectable peak representing $c y t-a a_{3}(600$ to $605 \mathrm{~nm})$. Nitrite oxidizers, on the other hand showed 3 distinct components: cyt-c, cyt- $a_{3}$

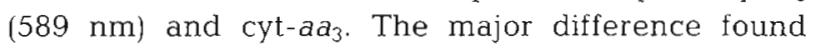
among the nitrite oxidizers was the ratio of cyt-a to cyt-c (greater for Nitrobacter sp. than for Nitrococcus mobilis). The variability in respiratory chains among soil Nitrobacter spp. has been recognized (Kirstein et al. 1986), especially with respect to different b-type cytochromes (558 to $564 \mathrm{~nm}$ ). These b-type cytochromes have been reported from both autotrophically and heterotrophically grown cells, yet this study did not detect $b$-type cytochromes in marine nitrite oxidizers grown chemoautotrophically. These findings did confirm the presence of a-type cytochromes, which have been described in autotrophic and mixotrophic cells. With 1 exception (cyt-b in nitrite oxidizers), the cytochrome composition of both types of nitrifying bacteria in this study agrees with previous reports. What cannot be ascertained is whether this is the prevalent pigment composition in natural habitats. Cytochrome analyses involve high cell biomass, and this is the primary problem when working with nitrifying bacteria due to their very low maximum specific growth rate and low growth yields. This obliges the physiologists working on nitrifiers to keep cultures growing at near-maximum specific growth rates. whirh by itself limits extrapolation of laboratory results to field conditions. Yet, until more sensitive methods of detecting respiratory pigments are developed, these results can at least indicate which cytochromes when present are suggestive of photosensitivity in ammonium oxidizers, or of phototolerance in nitrite oxidizers.

Acknowledgements. This work was supported by the National Science Foundation under grants OCE-8922815 and OCE-9416560. This is SERP contribution no. 39. 


\section{LITERATURE CITED}

Bock E (1965) Vergleichende Untersuchungen über die Wirkung sichtbaren Lichtes auf Nitrosomonas europaea und Nitrobacter winogradskyi. Arch Mikrobiol 51: $18-41$

Brain RD, Freeberg JA, Weiss CV, Briggs WR (1977) Blue light-induced absorbance changes in membrane fractions from corn and Neurospora. Plant Physiol 59:948-952

Diab S, Shilo M (1988) Effect of light on the activity and survival of Nitrosomonas $\mathrm{sp}$. and Nitrobacter $\mathrm{sp}$. isolates from fish ponds. Bamidgeh 40:50-56

Dispirito AA, Taaffe LR, Hooper AB (1985) Localization and concentration of hydroxylamine oxidoreductase and cytochromes $c-552, c-554, c_{\mathrm{m}}-553, c_{\mathrm{m}}-552$ and $a$ in Nitrosomonas europaea. Biochim Biophys Acta 806: 320-330

Epel B, Butler WL (1969) Cytochrome $\mathrm{a}_{3}$ : destruction by light. Science 166:621-622

Giese AC (1971) Photosensitization by natural pigments. In: Giese AC (ed) Photophysiology. Current topics in photobiology and photochemistry, Vol VI. Academic Press, New York, p $77-129$

Guerrero MA, Jones RD (1996a) Photoinhibition of marine nitrifying bacteria: wavelength dependent response. Mar Ecol Prog Ser 141:183-192

Guerrero MA, Jones RD (1996b) Dark recovery of marine nitrifying bacteria after monochromatic or polychromatic irradiation. Mar Ecol Prog Ser 141:193-198

Hooper AB, Logan M, Arciero M, McTavish H (1991) c-Cytochromes of the ammonia-oxidizing chemolithoautotrophic bacteria. Biochim Biophys Acta 1058:13-16

Jagger J (1983) Physiological effects of near-ultraviolet radiation on bacteria. Photochem Photobiol Rev 7:1-75

Jones RD, Morita RY, Koops HP, Watson SW (1988) A new marine oxidizing bacterium, Nitrosomonas cryotolerans sp. nov. Can J Microbiol 34:1122-1128

Responsible Subject Editor: Henry Blackburn, Aarhus, Denmark
Kirstein KO, Bock E, Miller DJ, Nicholas DJD (1986) Membrane-bound b-type cytochromes in Nitrobacter. FEMS Microbiol Lett 36:63-67

Lowry OH, Rosebrough NJ, Farr AL, Randall RJ (1951) Protein measurements with the Folin phenol reagent. J Biol Chem 193:265-275

Miller DJ, Wood PM (1982) Characterization of the c-type cytochromes of Nitrosomonas europaea with the aid of fluorescent gels. Biochem J 207:511-517

Müller-Neuglück M, Engel $\mathrm{H}$ (1961) Photoinaktivierung von Nitrobacter winogradskyi Buch. Arch Mikrobiol 39 $130-138$

Olson RJ (1981) Differential photoinhibition of marine nitrify. ing bacteria: a possible mechanism for the formation of the primary nitrite maximum. J Mar Res 39:227-238

Schön G, Engel H (1962) Den Einfluss des Lichtes auf Nitrosomonas europaea Win. Arch Microbiol 42:415-428

Smith L (1977) Bacterial cytochromes and their spectral characterization. In: Fleischer S, Packer L (eds) Methods in enzymology, Vol 53. Academic Press, New York, p 202-215

Tanaka Y, Fukumori Y, Yamanaka T (1983) Purification of cytochrome a1c1 from Nitrobacter agilis and characterization of nitrite oxidation system of the bacterium. Arch Microbiol 135:265-271

Tsai YL, Tuovinen OH (1989) Influence of metals on oxygen uptake, carbon dioxide fixation, and cytochrome reduction in Nitrobacter agilis. Toxic Assess 4:185-198

Vanzella A, Guerrero MA, Jones RD (1989) Effect of CO and light on ammonium and nitrite oxidation by chemolithotrophic bacteria. Mar Ecol Prog Ser 57:69-76

Woese CR, Weisburg WG, Hahn CM, Paster BJ, Zablen LB, Lewis BJ, Macke TJ, Ludwig W. Stackenbrandt E (1985) The phylogeny of purple bacteria: the gamma subdivision. Syst Appl Microbiol 6:25-33

Yoshioka T, Saijo Y (1984) Photoinhibition and recovery of $\mathrm{NH}_{4}{ }^{+}$-oxidizing bacteria and $\mathrm{NO}_{2}{ }^{-}$-oxidizing bacteria J Gen Appl Microbiol 30:151-166

Manuscript received: January 10,1997

Revised version accepted: April 22, 1997 